\title{
Essais
}

ESSAIS

Revue interdisciplinaire d'Humanités

Hors-série 4 | 2018

Stanley Kubrick

\section{From Zoom to Zoom. An evidential interpretation of The Shining}

Loig Le Bihan

\section{(2) OpenEdition}

1 Journals

Electronic version

URL: http://journals.openedition.org/essais/610

DOI: 10.4000/essais.610

ISSN: 2276-0970

Publisher

École doctorale Montaigne Humanités

Printed version

Date of publication: 1 July 2018

Number of pages: 61-77

ISBN: 979-10-97024-04-8

ISSN: $2417-4211$

\section{Electronic reference}

Loig Le Bihan, «From Zoom to Zoom. An evidential interpretation of The Shining », Essais [Online], Hors-série 4 | 2018, Online since 01 December 2019, connection on 16 December 2019. URL : http:// journals.openedition.org/essais/610; DOI : 10.4000/essais.610 


\section{From Zoom to Zoom. An evidential interpretation of The Shining}

\section{Loig Le Bihan}

The Shining's genesis, that one may attempt to retrace thanks not only to the testimonies of some of the production's key actors - chief among them Stanley Kubrick and his cowriter Diane Johnson- but also to the many documents stored in the Stanley Kubrick Archives ${ }^{1}$ in London, reveals the complexity of a long-lasting creative process which seems to have branched off its original agenda. If the initial ambition was to adapt Stephen King's novel freely while inscribing the film within the tradition of a genre, it does seem -as I have argued at length in my book Shining au miroir ${ }^{2}-$ that the film's creative path has somehow strayed away from this project. In order to shed light on the process which led from King's novel to Kubrick's film, one must proceed with a particular kind of interpretation, an "evidential interpretation".

\section{Evidential interpretation}

Ever since the publication of Carlo Ginzburg's foundational Clues: Roots of an Evidential Paradigm, the expression "evidential interpretation" refers to a form of conjectural thought sometimes also referred to as "Zadig's Method", which is common in various human activities; it is the method of a hunter, of an investigator, a doctor or a philologist. It aims at inferring "retrospective prophecies" from traces which one constitutes as clues ${ }^{3}$.

1 The Stanley Kubrick Archives are situated in the London College of Communication, University of the Arts London. The catalogue is available online in the UAL website: http:// archives.arts.ac.uk.

2 Loig Le Bihan, Shining au miroir. Surinterprétations, Paris, éd. Rouge profond, coll. «Raccords », 2017.

3 Carlo Ginzburg, "Traces. Racines d'un paradigme indiciaire " [1979], in Mythes, emblèmes, traces, Lagrasse, Éditions Verdier, coll. « Poche», 2010. 
Drawing on Ginzburg's theory, philologist Glenn Most proposes a more precise distinction between various "evidential paradigms" and states that "the one required in philology is not medical, but judiciary in nature" . He adds:

that which philologists have in common with jurists and which sets them both apart from doctors cannot be apprehended in terms of categories such as the division between the individual and the general, since all three practices deal with a unique subject (the text, the specific case or the patient) which may lead to generalities through a complex path one cannot fully theorize [...]. The operational categories thus required are the opposition between intent and action on the one hand, cause and effect on the other. [...] A poem, like a murder, traces back to a behaviour and cannot be fully comprehended unless one strives to reconstruct the intentionality it presupposes, and which leaves behind a material residue, the trace. Of course an intention precedes and in some way determines an action, just like a cause precedes and in some way determines an effect. [...] On the other hand, there can certainly be actions devoid of intention and intentions devoid of actions - my own life at least is filled with these. The fact that action and intention belong to distinct ontological realms contrarily to cause and effect helps us see why the explanation of a causal relation may be exhaustive and intact whereas the interpretation of an intentional relation may only be speculative and approximate. ${ }^{5}$

Drawing on those premises, Glenn Most indicates that evidential interpretation in textual philology must consist in reconstituting from the text itself a hypothetical intention, not from one single clue but out of an array of concordant clues, which he calls an "intentional structure". Thus, he chooses to focus solely on the traces which permit to assume (what I shall call) a structuring intention within the author's mind, and not on the traces that would, for instance, betray unintentional creative actions or even on the traces of isolated, disseminated intentions. In this regard, he deeply concurs with Umberto Eco's view that the search for semiotic coherence is the best criteria to determine the probability of an intentio operis -literally, the "work's intention".

How, then, shall one aim to achieve an evidential interpretation with regard to a film? The making of a film is more complex than the writing of a poem -possibly even more so, dare I add, than the planning of a murder- since it is a long process, fragmented into several successive steps (development, pre-production, production and post-production). It is both a collective and a hierarchical process as it requires many people to provide contributions throughout different steps of the process, contributions which vary in nature -either executive, contributive or decisive. It is also a highly concrete process and, as such, extremely dependent on circumstantial causalities and unin-

4 Glenn W. Most, "Philologie et interprétation indiciaire ", in Denis Thouard (éd.), L'Interprétation des indices. Enquête sur le paradigme indiciaire avec Carlo Ginzburg, Villeneuve d'Ascq, Presses universitaires du Septentrion, coll. « Opuscules », 2007, p. 65.

5 Ibid., p. 67-68. 
tentionalized actions. So that a film's evidential interpretation which aims at retrospectively prophesying a creative process shall not be limited to the conjectural reconstruction of a structuring intention, nor even to sorting out traces of intentional and unintentional actions. It must also take into account causal necessities and material contingencies.

In the first part of my book which is mostly centred on an evidential interpretation of The Shining, I first sought to reconstitute the logic of the film by attempting to sort out the clues of intentional structure, the vestiges of initial or transitory intentions and the traces of circumstancial causalities within the work. By confronting the film's logic to the clues of a structuring intention from the perspective of the intentio auctoris, I believe I managed to extract the common thread of a diachronic and purposed creative process out of the episodic, anecdotal chronicle of the film production. For the purpose of this article, I will not attempt to synthesize all that I submit in my book; I will rather investigate the genesis of a scene which, to my view, most condenses what one may call, following Etienne Souriau, the "truth of instauration" (vérité d'instauration) of Kubrick's work ${ }^{6}$. I shall therefore delve into a "micro-genetic" foray -as is said in genetic Criticism- of the successive strata of one particular scene. Namely, the first one from the fourth part of the screenplay, which is named after an object - The Scrapbook- and which corresponds, in the final film, to the one where Jack idly roams around the hotel and ends up bending over the maze's model, while Wendy and Danny are visiting the maze.

\section{A "micro-genetic" incursion into a few scenes of The Shining}

Let us focus on the "elective" moment which symbolizes a major shift in the film's genesis and in its instauration (the process through which the creator's attention to the upcoming work's own necessity eventually dictates the artist's choices). In order to simplify the restitution of such a complex shift, I will describe three different states of a narrative episode whose function remained the same for a long time: it was meant to indicate the decisive moment in which the hotel tightens its grip on Jack. Initially thought of as an "enchantment" -and eventually "occulted"-, the moment of Jack's subjugation coincided for a long time, as it does in King's novel, with his stumbling upon an evil object -that is, a scrapbook filled with press cuttings relating the hotel's sinister tale.

6 On Souriau's notion of artistic instauration, one may read one of his texts which best summarize his thought: "Du mode d'existence de l'œuvre à faire” (1956), rééd. in Étienne Souriau, Les différents modes d'existence, Paris, éd. PUF, coll. "Métaphysiques ", 2009, p. 195-217. Regarding the notion of "truth of instauration", cf. Ngô-tiêng-Hiên's analysis, "Art et vérité dans l'œuvre d'Étienne Souriau ", in Revue philosophie de Louvain, 4e série, t. 69, n 1, 1971, p. 73-91; doi :10.3406/phlou.1971.5589. 
I will thereafter refer to several states of the shooting script so as to examine the variants between a state I shall here refer to as "initial" -corresponding to the succession of events as prescribed by the shooting script finalized on April $2^{\text {nd }}$ and used by the team during the beginning of the shooting on May $2^{\text {nd }} 1978$ - another I shall call "transitory" -referring to the description of the events as it was altered after the first weeks of shooting, on the $23^{\text {rd }}$ and $29^{\text {th }}$ of May 1978- and a "final" state, that is to say the events as they occur almost identically in the two known versions of the film completed in $1980^{8}$.

The final state / Jack roaming around the hotel; Wendy and Danny visiting the maze (European version, 00:24:39 to 00:27:16 / American version, 00:37:25 to 00:40:19)

One will recall that after Jack, barely awake, discusses with the enthusiastic Wendy who came to bring him breakfast in bed, the next shot opens on a slow backwards tracking shot centered on Jack's typing machine laying on his desk (Ill.1); it then reveals the character of Jack bouncing a tennis ball over the hearth of the Colorado Lounge (Ill.2). Meanwhile, Wendy and Danny run into the maze, in which they will lose themselves for a while (Ill.3). After a dissolve indicating the simultaneity of the events (Ill.4), Jack gets near the maze's model and stops to scrutinize it (Ill.5). The shot cuts to a long shot overhanging the real maze, zooming until one may discern the tiny effigies of Wendy and Danny who have reached the centre of the labyrinth (Ill.6). Thanks to the montage, one may wonder whether a fantastic occurrence of clairvoyance is going on. The scene ends with the irruption of the intertitle card "Tuesday".

The transitory state / The scrapbook is found on the working desk (SK/15/1/35 "D. Parker Bound Script", scenes 45 to 47)

Quoted below are the scenes which correspond to this moment in the film as they are described in a transitory state of the screenwriting program, one that can be found in a document available in the Stanley Kubrick Archives under the title "D. Parker Bound Script", numbered "SK/15/1/35". The alterations dated 22/05/78 are in italics, those from 29/05/78 are in bold letters. Scene 46, whose paragraph is here indented, was cancelled in the screenplay dated $29 / 05 / 78$. Underlining is from the original document.

7 "Initial" here does not qualify an "original" state. I term this state "initial" as it is the state the narrative was stabilized in at the end of the development period and at the beginning of the production process.

8 On the various versions of Kubrick's film, cf. chapter "Les trois versions" from my book, Shining au miroir, op. cit., p. 101-104. 
SCENE 45 - LOUNGE - DAY

Jack is seated at a large table which he has arranged for his writing. It has, neatly placed upon it, a typewriter, pencils, paper, stapler, scotch tape, ruler, etc. But he is not working, and, after a while, he rises wearily, sighs and exits.

SCENE 46 - LOBBY - DAY - DELETED

Wendy is seated on a couch with Danny watching a TV film. Jack enters. Wendy looks up.

WENDY - It's almost over. Why don't you sit down?

JACK - No, thanks. I've seen it already a couple of hundred times.

WENDY - How's it going?

JACK - Fine. (meaning, not working)

WENDY - Where're you off to?

JACK - I'm going to earn my money. I haven't looked at anything for a week. WENDY - Come back when you're through and we can have some coffee. JACK - Okay. See you later.

He exits.

Now substituted by MAZE - INT - SCENE 55

SCENE 55 - MAZE - INSIDE - WALKWAYS

Series of shots of Wendy and Danny wandering through the maze. Various ad libs about whether they should go this way or that way, and what Tony thinks. DANNY - How come Dad never comes out with us anymore?

WENDY - Oh, he's real busy working on his book.

DANNY - He sure works hard.

WENDY - Yes, he does.

DANNY - He's happy now, isn't he?

WENDY - Yes, he really is happy.

\section{SCENE 55A - MAZE CENTRE - PROMENADE}

They find their way to the centre and Danny runs in laughing. WENDY - It's so peaceful in here, and pretty. It's like a magic forest.

She takes out her Polaroid. Eventually, they find the centre of the maze, with rows of arches opening to it.

DANNY - Hooray, we made it !

WENDY - (looking at her watch) It took us twenty minutes this time. We're getting good.

Wendy takes out her Polaroid camera.

WENDY - Danny, stand over there for a minute, and I'll take your picture.

Danny laughs and poses for the picture. Wendys snaps it. It starts to snow lightly and a fresh wind picks up. Wendy shivers.

WENDY - I think we'd better start going back now, Doc - it's starting to snow.

SCENE 47 - LOBBY - DAY

Jack enters and stops to examine the model of the maze. We will intercut a shot of Wendy and Danny now in the maze to go against this.

DISSOLVE

\section{SCENE 47A - LOBBY - BALLROOM WALKOFF - DAY}

Jack enters and walks toward the ballroom. This sequence of Jack wandering around the hotel will be accompanied by a strange, magical music montage mixed with just audible sounds of laughter, conversation and activity. It will convey a sense of magic echoes of the past, and an ominous sense of Jack's enchantment by the hotel.

DISSOLVE 


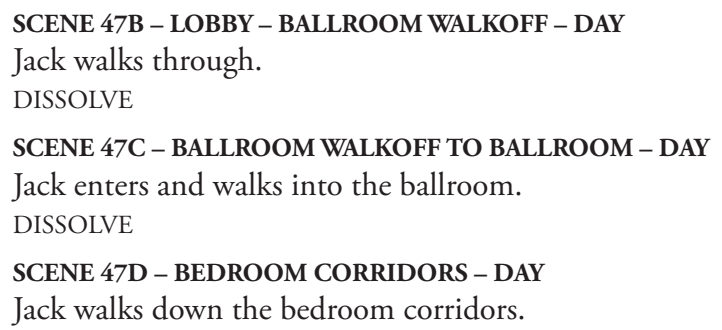

SCENE 47E - MEZZANINE - DAY - SCRAPBOOK ZOOM

Jack enters the mezzanine and looks down at the lounge below.

We will see his work table and slowly zoom down to the Scrapbook which has mysterious been placed on his table during his walk around.

We know that Wendy and Danny are still in the maze. The music builds on the zoom.

DISSOLVE

SCENE 47F - LOUNGE - DAY

Jack enters the lounge, walks to the table and opens the pages of the Scrapbook.

The music will build on this, too.

In this transitory state, one may notice a few variations from the final state, notably the suppression of the end of scene 55A. If Wendy does stroll with her Polaroid camera in hand, it is no longer used to photograph Danny once they have reached the centre and she tells Danny they have beat their best time, before she warns him it is time to go home as it will snow soon. But one may also notice two sets of modifications as regards the original state of events: first, the suppression of a dialogue between Wendy and Jack -scene 46during which she invites him to sit by her side and Jack replies he will rather go "earn [his] money", by which he means draining the boiler to prevent its overheating'; then the significant expansion of scene 47, now extended with several new scenes $\left(47^{A}\right.$ to $\left.47^{\mathrm{F}}\right)$. Scene 47 in its initial state merely showed Jack roaming around "his" hotel before finding the scrapbook lying among a pile of stuff in scene 48. Therefore, in this transitory state, the scrapbook is not unearthed by Jack from the basement anymore; via a "SCRAPBOOK ZOOM", it is merely found by Jack upon his desk, as it was put there, but by whom?

The initial state / Reading the scrapbook in the basement (SK/15/1/24 "Annotated Bound Script", Scenes 47 to 48)

Let us now see the way Jack found the scrapbook and took it up in the initial state of the script...

9 In Stephen King's novel as well as in the telefilm he produced (Stephen King's The Shining, Mick Garris, 1997), the boiler is the hotel's real beating heart. Its explosion triggers the final destruction of the place. 
SCENE 47 - VARIOUS PLACES IN THE HOTEL - DAY

A series of shot of Jack walking through the hotel, which he gazes at with such a fondness that one might think he had come home after a long absence.

SCENE 48 - BASEMENT - DAY

Jack enters to check the boiler. When he is through, he shifts his attention to the stacks of boxes and crates, stuffed with papers, old files, invoices, etc.

He notices a scrapbook, covered with dust on top of some boxes. He picks it up and starts to look at it.

We see pages with early photographs of the hotel; newspaper clippings pasted on them which document the lurid and sinister history of the hotel: murders, suicides, and fatal accidents involving its legendary rich and famous clientele.

An invitation card flutters to the floor. It reads :

The Overlook Hotel

Request the Pleasure of Your Company

At a Masked Ball

To celebrate New Year's Eve

Dinner will be served at $8 \mathrm{pm}$

Unmasking and Dancing at Midnight

December 31 st, 1919

We will film a visual impression of Jack spending hours sitting on the floor of the basement, pouring through the pages of the scrapbook.

We will also show close-ups of the stories he's looking at.

The cinematic approach, supported by the music, will be to suggest a sens of evil enchantment.

Jack reads from a crumpled sheet of violet ladies' stationery, which is pasted in the book. It is dated $13^{\text {th }}, 1932$.

JACK - "Dearest Tommy, I can't think so well up here, as I'd hoped, about us, I mean. Of course, who else? Ha. Ha. Things keep getting in the way. I've had some strange dreams about things going bump in the night, can you believe that? And..."

The writing suddenly stops.

Jack looks at a menu, pasted on one of the pages and we see scribbled in pencil:

"Medoc

Are you here?

I've been sleepwalking again, my dear.

The plants are moving under the rug."

One of the newspaper headlines says: "Gangland Style shooting in Colorado

Hotel" and written next to it in pen: "And they took his balls along with them."

This scene 48 was eventually suppressed from the film, as was scene 46 . The scenes that follow and conclude the fourth part of the screenplay, scenes 49 and 50 -quite logically displaced to the living room in the transitory state- were also suppressed. In these, Wendy, worried by Jack's long absence, decided to go look for him; once found, they engaged in a conversation during which Jack would enthusiastically tell her about his wish to use the content of the scrapbook for a new writing project. As for scene 47: after being altered between the initial state and the transitory state so as to introduce a synchronicity between Jack's roaming within the hotel and Wendy 
and Danny's exploration of the maze, and extended in a serie (scene 47A to 47F), it was finally trimmed from this succession of brief scenes in which the discovery of the scrapbook (initially found in scene 48) had been displaced

\section{From zoom to zoom / from the initial to the final intention}

In the completed film, though the scenes of the discovery of the scrapbook are gone, they have nonetheless left something like "the smell of burnt toast", in the words of Halloran. An indelible vestige remained in the film in the form of this prop lying on Jack's desk. Even though it is somehow "inhibited" from the film's narrative logic and, for this very reason, few spectators may notice the scrapbook, it does appear in the following scene which shows Jack working (Ill.7), soon to be interrupted by his wife telling him snow has been forecast (IIl.8); it even appears in the foreground (III.9)...

Diane Johnson repeatedly expressed her regret about the suppression of those scenes in which Jack discovered the scrapbook and then discussed with his wife. In a 1999 interview with Nicolas Saada, shortly after Kubrick's death, she states: "in the novel, the character's fairly weak nature led him to succumb to the ghosts' influence. He became the hotel's creature, controlled by the ghosts. A scene was shot but suppressed during post-production: Jack Torrance (Jack Nicholson) finds a scrapbook filled with pictures and press cuttings telling the hotel's history, articles alluding to the murder of the two little girls and to other events connected to the ghosts haunting the hotel" 10 . In another interview published in 2011, she adds: "He actually took out a scene that I considered more important [than the original ending scene]. If you've read the novel, it's the scene were Jack finds the scrapbook in the boiler room. And I thought that was very important because you had to know the moment in which he came under the control of the hotel. It's like the moment in a fairy story when the hero takes the poison apple. The main character makes a mistake that brings them into the grip of evil. That was when Jack made his mistake. Before that, it could have gone either way. It's his vanity and his hope to be a great writer that leads him to take this scrapbook as a gold mine of subjects. That was written and shot. I was sorry to see that Kubrick cut that out. I would have argued to take out something else"11.

The co-writer has a hard time getting over the loss of the scrapbook scenes, so useful were they, in her mind, to foster the understanding of the narrative according to a generic horizon of expectation. From the moment Jack discovered the scrapbook and decided to make a novel out of it, the film was on

10 Nicolas Saada, "The Shining, une histoire de famille. Entretien avec Diane Johnson", Cahiers du cinéma, $\mathrm{n}^{\circ}$ 534, Avril 1999, p. 35.

11 Mark Steensland, "The Shining Adapted. An interview with author Diane Johnson", Kamera, n², republished by the blog: The Terror Trap, mai 2011. [Terrortrap.com (last accessed 5/12/2016).] my emphasis. 
track, its generic "rails" were clearly set up. And yet her very statement could explain the reason why the scrapbook "disappeared" more satisfactorily than the motives generally put forward -even by Johnson herself ${ }^{12}-$ of duration requirements, which justify little. Indeed, once the scrapbook discovered, the range of potential paths would narrow down to only leave room for one, namely Jack being possessed by the hotel's history. During the decisive moment of editing, did Kubrick end up considering the scrapbook to be an excessively determining object, to the point of being cumbersome?

In order to partially ${ }^{13}$ (though, I believe, probingly) answer this question, one must highlight what the late invention of the MAZE ZOOM owes to its antecedent, the SCRAPBOOK ZOOM -which did get shot, as Ray Andrew asserted $^{14}$. Unplanned during the writing of scene 55, shot at a late stage, the MAZE ZOOM is some sort of "patch". It is no trifling detail if the zoom on the scrapbook in scene $47^{\mathrm{E}}$, which was thought of as the moment in which the hotel's haunting take on Jack crystallizes (and whose importance is literally underlined in the typescript), was replaced formally by this singular, yet equally "overlooking", shot of the MAZE ZOOM. From an evidential interpretative perspective, this substitution reveals the occultation of this turning point -getting under the scrapbook's spell-which is now missing; but it also entails some sort of equivalent promotion for the maze. This decisive -shot for shot- substitution of a SCRAPBOOK ZOOM by a MAZE ZOOM seems to me to mark a turnaround in the film, which leaves the register of the Gothic and enters a radical form of the Fantastic. It reveals something very deep regarding what one may term the author's final structuring intention.

This "matrix" shot ${ }^{15}$, inserted late so as to fill the void left by the late suppression of a formally similar shot, emblematizes the film as a whole, which is not now scary so much as it is uncanny, in the full -Freudian-sense of the word. For the labyrinthine feeling of irremeabilis error ("inexorable wandering"16) is closer to what Freud aims at analyzing in his essay on "The Uncanny" -which is known to have been used as a source of inspiration for the cowriters, along with Bruno Bettleheim's The Uses of Enchantment. Such acquaintance is made clear upon rereading Freud's text.

12 Diane Johnson, "Writing The Shining" in Geoffrey Cocks, James Diedrick, Glenn Perusek (éd.), Depth of Field. Stanley Kubrick, Film, and the Uses of History, Wisconsin, The University of Wisconsin Press, coll. "Wisconsin Film Studies", 2006, p. 58.

13 I say partially because the "case" of the scrapbook has been subject to many hesitations as to what it should contain, notably through a hiatus between a "scripted" scrapbook and a "crafted" scrapbook. Those hesitations might justify why it became cumbersome. Cf. my book, section D'un album disparu, p. 67-83.

14 Cf. "Ray Andrew. Interview by Justin Bozung", in Danel Olson (éd.), The Shining. Studies in the Horror Film, Lakewood, Centipede Press, p. 721-722.

15 Cf. my book, section "La matrice de l'Overlook", in Shining au miroir, op. cit., p. 193-200.

16 A term valued by Paolo Santarcangeli in his classic Le livre des labyrinthes (1967), Paris, NRF-Gallimard, coll. "Bibliothèque des idées", 1974. 
Strolling one hot summer afternoon through the empty and to me unfamiliar streets of a small Italian town, I found myself in a district about whose character I could not long remain in doubt. Only heavily made-up women were to be seen at the windows of the little houses, and I hastily left the narrow street at the next turning. However, after wandering about for some time without asking the way, I suddenly found myself back on the same street, where my presence began to attract attention. Once more I hurried away, only to return there again by a different route. I was now seized by a feeling that I can only describe as uncanny [unheimlich], and I was glad to find my way back to the piazza that I had recently left and refrain from any further voyages of discovery ${ }^{17}$.

It is this aesthetics of the uncanny which finally imposed itself in the instauration of the film. It thus subordinates the generic remains remotely inherited from fairy-tales and eventually "works" against the entire archigenesis ${ }^{18}$ of the Gothic which nonetheless impacted deeply on the development process -one may notably keep in mind that the hotel was built upon an Indian burial ground, an invention of the two cowriters which perfectly fits the genre. The Shining's MAZE ZOOM reveals this idea of the film, an idea which finally imposed itself on Kubrick in such a way that it ultimately led to the ruin of the genre film which The Shining might have been, had the initial intention been firmly respected until the end; if, in particular, the scrapbook scenes had been kept.

If one considers how much a kind of "labyrinthine necessity" governed the deep reorientation the idea of the film went through in the ongoing process of its instauration, one better understands the occultation of the scrapbook scene as well as the accumulation of narrative dead-ends. It highlights, for instance, the logic which governs the heteroclite patchwork of insane visions Wendy experiences at the end of the narrative. This kind of carnival of seemingly disconnected apparitions is the ultimate result of the film's process of indetermination. While Diane Johnson had claimed it had to "have no holes in the plot"19, Kubrick, however, ended up saying upon the film's French release that "like a maze, it is filled with false exits and dead-ends" ${ }^{20}$.

Loig Le Bihan

EA 4209 - RIRRA 21

Université Paul Valéry Montpellier 3 RIRRA 21 - EA 4209, Montpellier (France) loig.le-bihan@univ-montp3.fr

17 Sigmund Freud, The uncanny. New York: Penguin Books, 2003, p. 144.

18 Through this neologism, I refer to the influence of the frames of the genre as well as to that of the "architext" (in Gérard Genette's definition of the term) on the work's genesis.

19 Aljean Harmetz, "Kubrick Films The Shining in Secrecy in English Studio", The New York Times, 6 November 1978.

20 Robert Benayoun, "Kubrick : “Tous les fous n'ont pas l'air d'être fous” (entretien avec Stanley Kubrick ) ", Le Point, n 422, 20 ctobre 1980, p. 181. 


\title{
Résumé
}

La genèse de Shining témoigne de la complexité d'un long processus de création qui semble avoir, en certains moments décisifs, bifurqué. Si l'idée de départ était d'adapter librement le roman de Stephen King tout en inscrivant pleinement le film dans la tradition d'un genre, le trajet de la production aura quelque peu dévoyé ce projet. Pour restaurer quelque chose de ce processus qui aura mené depuis le substrat du roman de King jusqu'à l'achèvement du film de Kubrick, il faut procéder à un type bien particulier d'interprétation, qu'on peut dire, avec Carlo Ginzburg, "indiciaire ». On proposera, à l'occasion de cet article, une incursion " micro-génétique " qui visera à remonter le cours des différents états d'une scène emblématique marquée notamment par la disparition finale d'un "zoom sur un album " (SCRAPBOOK ZOOM) remplacé in extremis par un "zoom sur un labyrinthe " (MAZE ZOOM). Cet événement de détail dans la genèse du film condense au plus haut point ce qu'on pourrait appeler, avec Étienne Souriau, la « vérité d'instauration » de l'œuvre de Stanley Kubrick.

\section{Mots-clés}

Shining, interprétation indiciaire, critique génétique, intention hypothétique/réelle, instauration poḯtique.

\begin{abstract}
The Shining's genesis reveals the complexity of a long-lasting creative process which seems to have branched off its original agenda at some key moments. If the initial ambition was to adapt Stephen King's novel freely while inscribing the film within the tradition of a genre, it does seem that the film's creative path has somehow strayed away from this project. In order to shed light on the process which led from King's novel to Kubrick's film, one must proceed with a particular kind of interpretation, what Carlo Ginzburg terms an "evidential interpretation". Throughout this article, I will delve into a "micro-genetic" incursion into the various strata of an emblematic scene marked by the final suppression of a SCRAPBOOK ZOOM, replaced in extremis by a MAZE ZOOM. This detail of the film's genesis concentrates to the utmost what one may call, following Etienne Souriau, the "truth of instauration" of Stanley Kubrick's work.
\end{abstract}

\section{Keywords}

The Shining, evidential interpretation, genetic criticism, hypothetical/actual intention, poietic inception. 


\section{NOTICE BIOGRAPHIQUE}

Maître de conférences en études cinématographiques à l'université Paul Valéry (Montpellier 3), Loig Le Bihan enseigne les méthodes de l'analyse filmique. Il a été co-éditeur de la revue d'esthétique du cinéma Cinergon de 1995 à 2010 et est actuellement co-responsable du groupe de recherche "Analyse " au sein de l'Equipe d'Accueil RIRRA 21 de l'université Paul Valéry. Il a dernièrement publié un ouvrage consacré à la genèse et aux interprétations de Shining (Shining au miroir, Aix-en Provence, éd. Rouge Profond, coll. " Raccords ", 2017, 393 p.) 


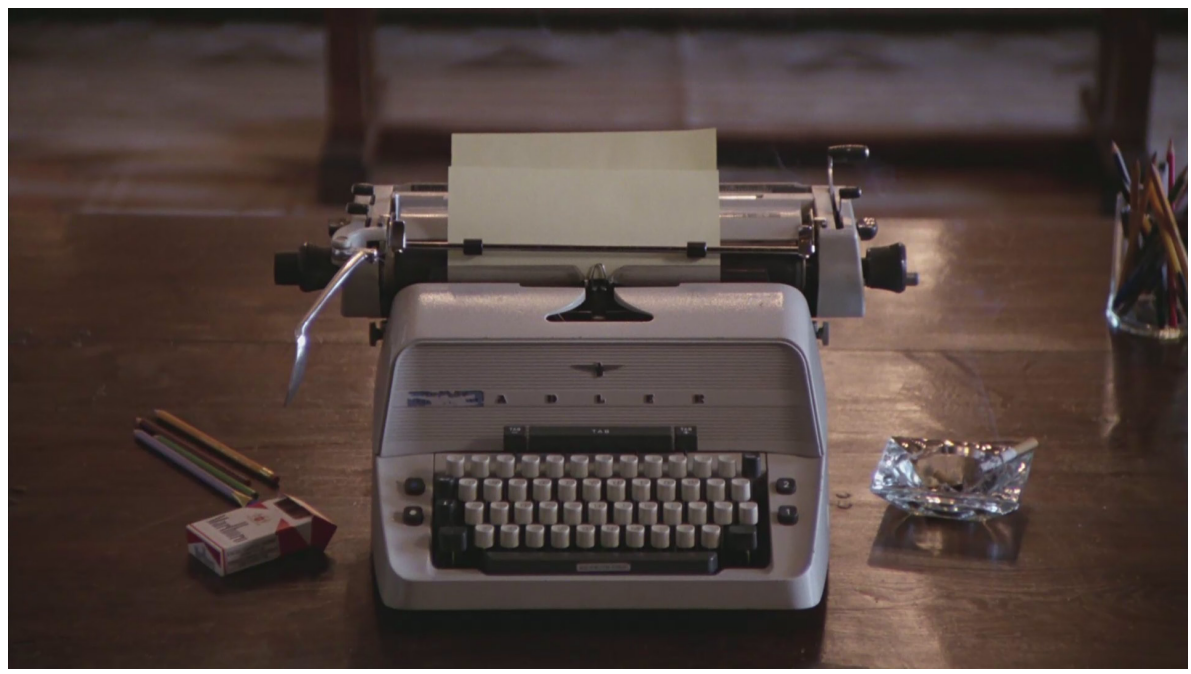

Ill.1

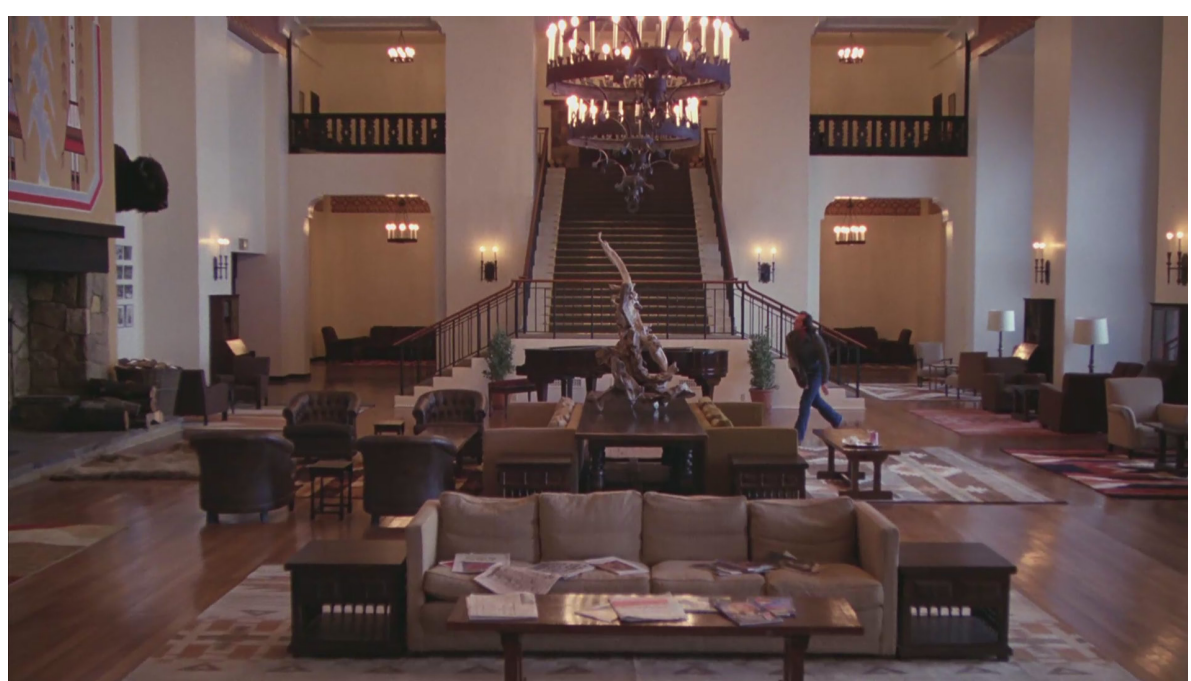

Ill.2 


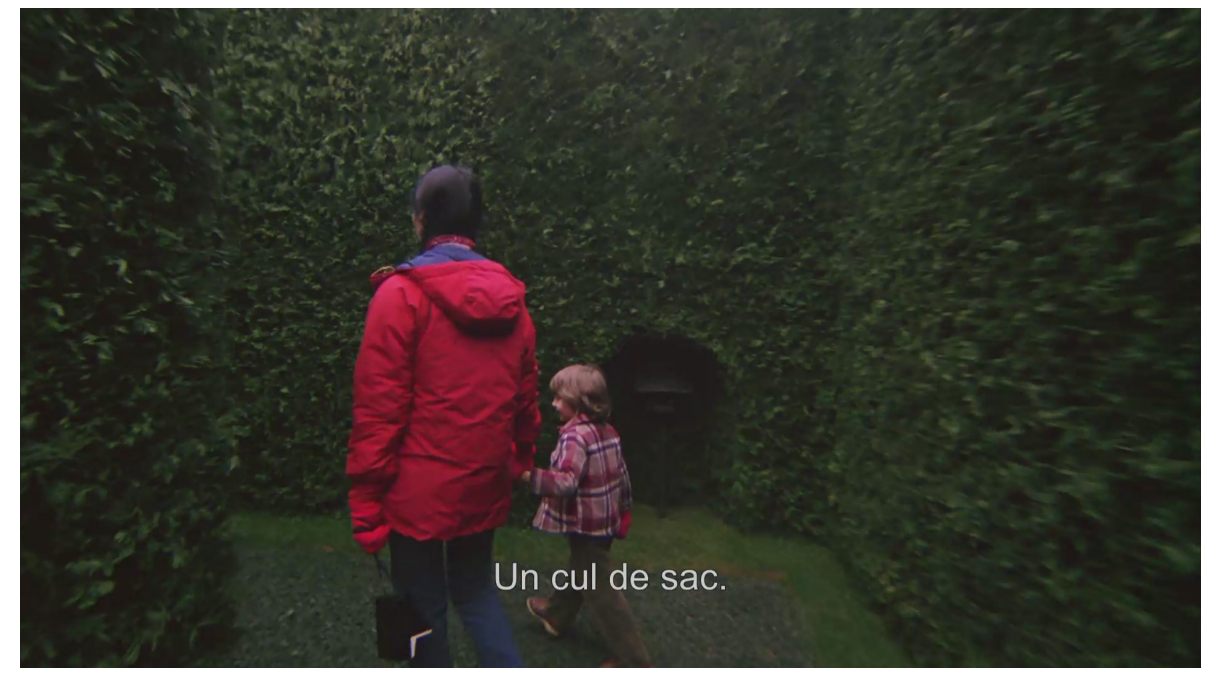

Ill.3

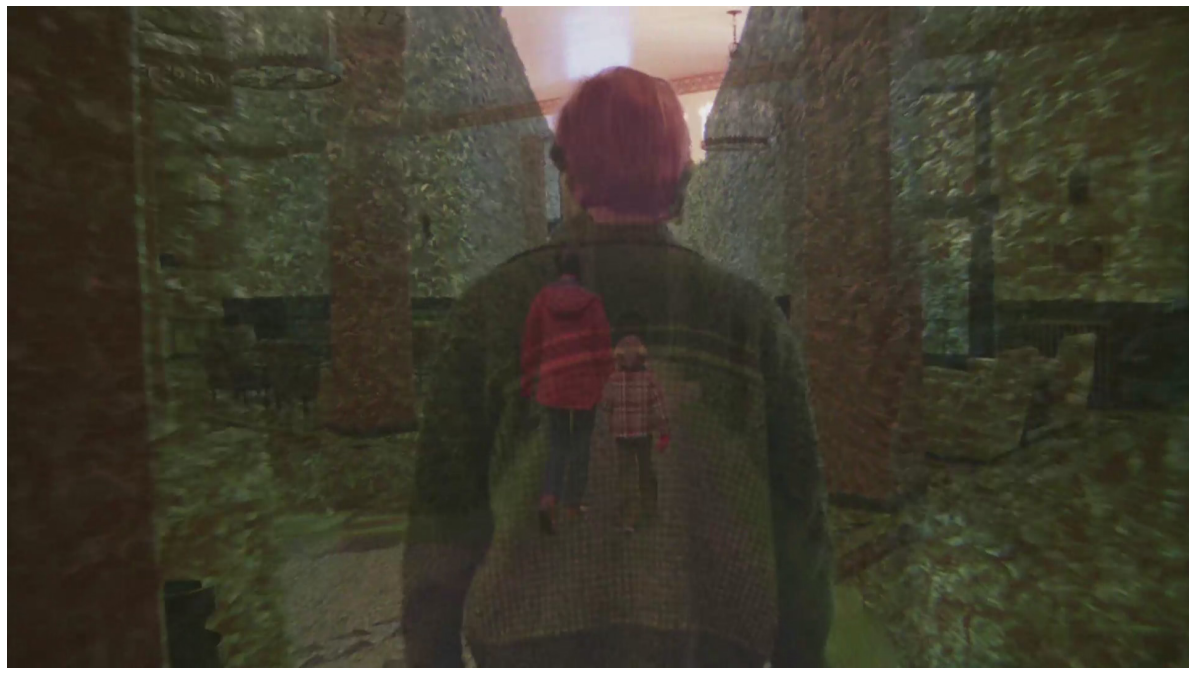

Ill.4 


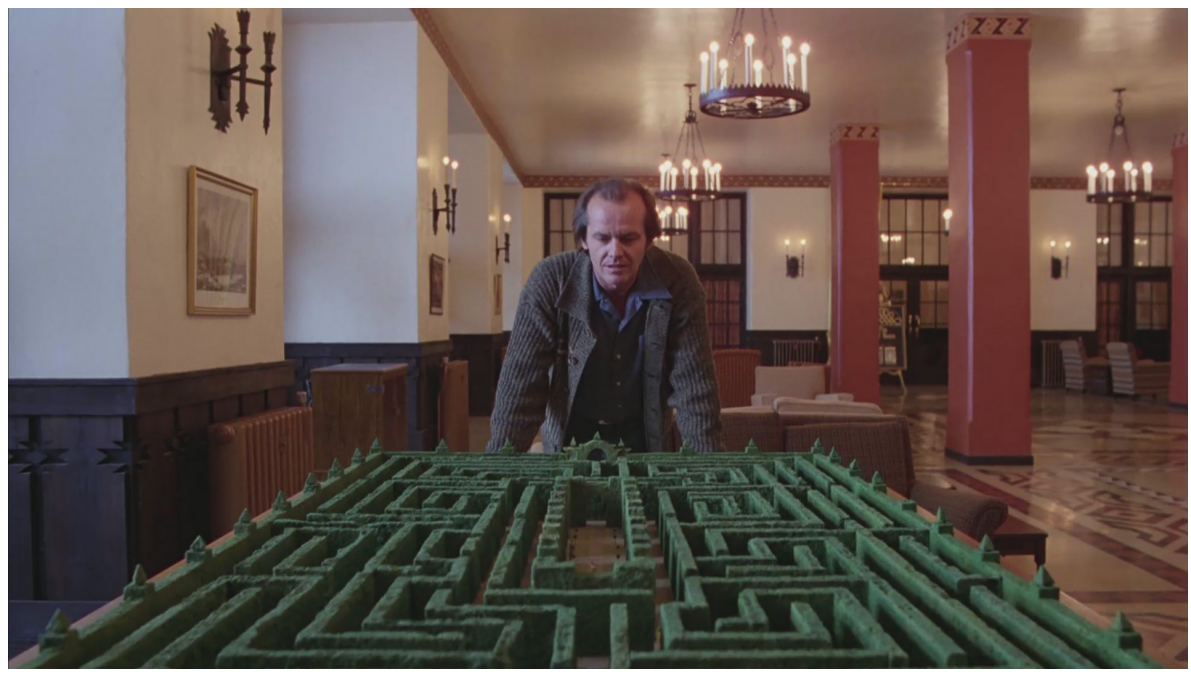

Ill. 5

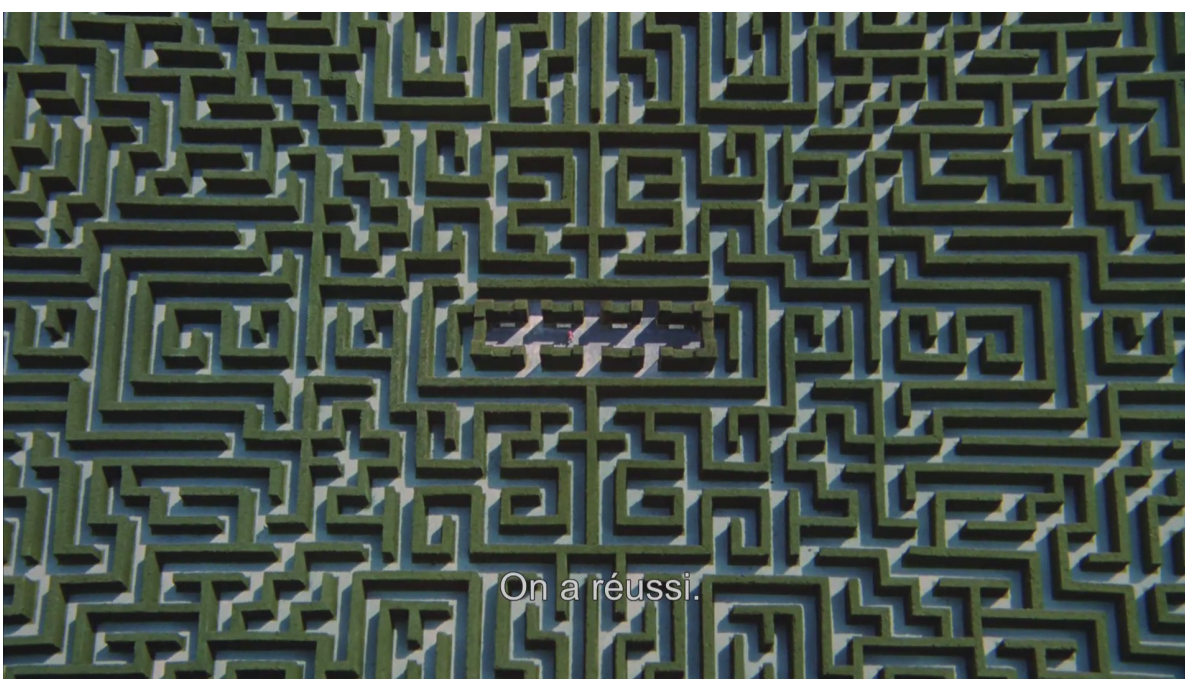

Ill.6 


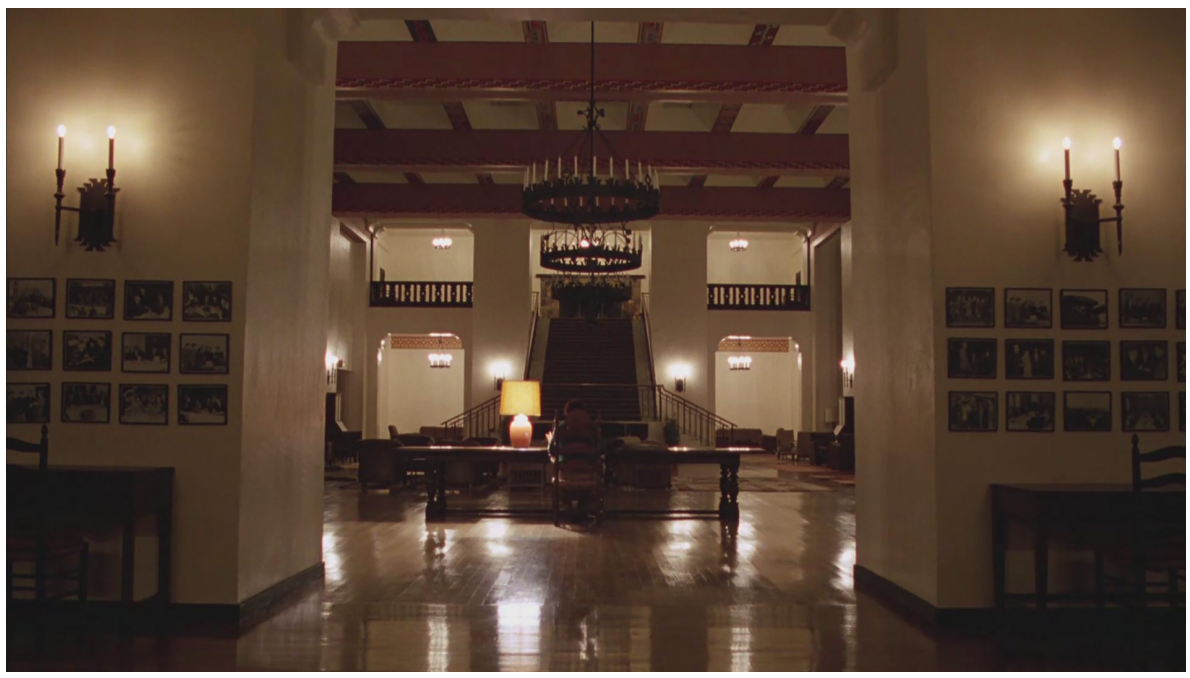

Ill.7

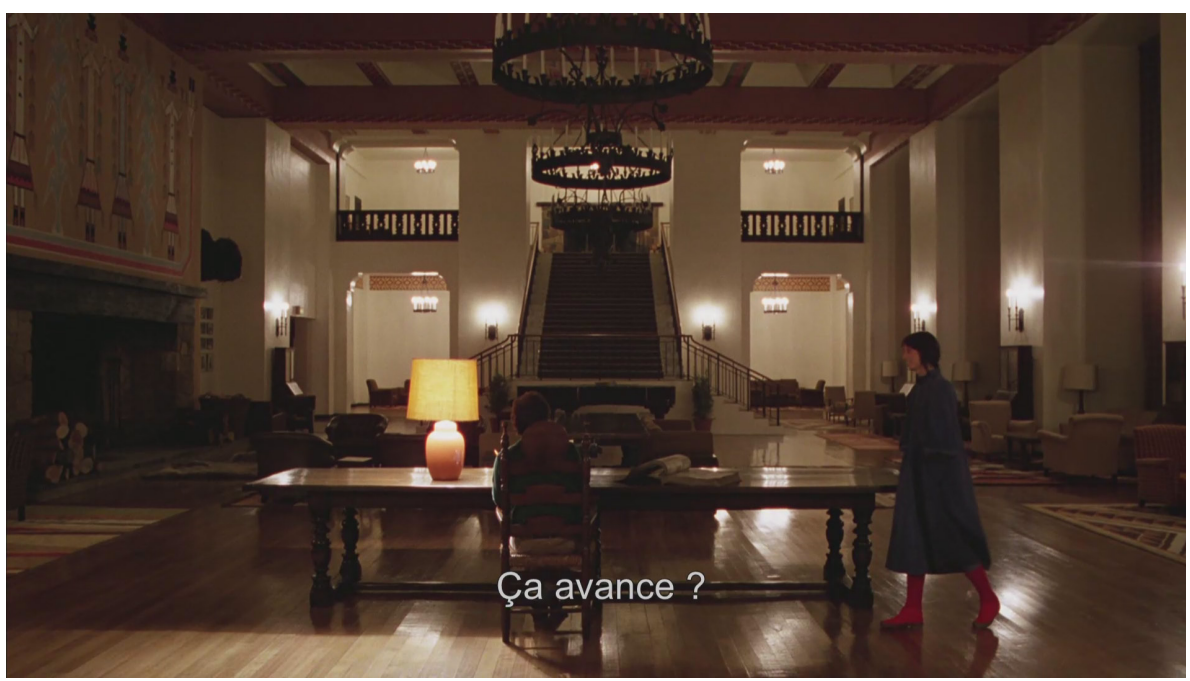

Ill.8 


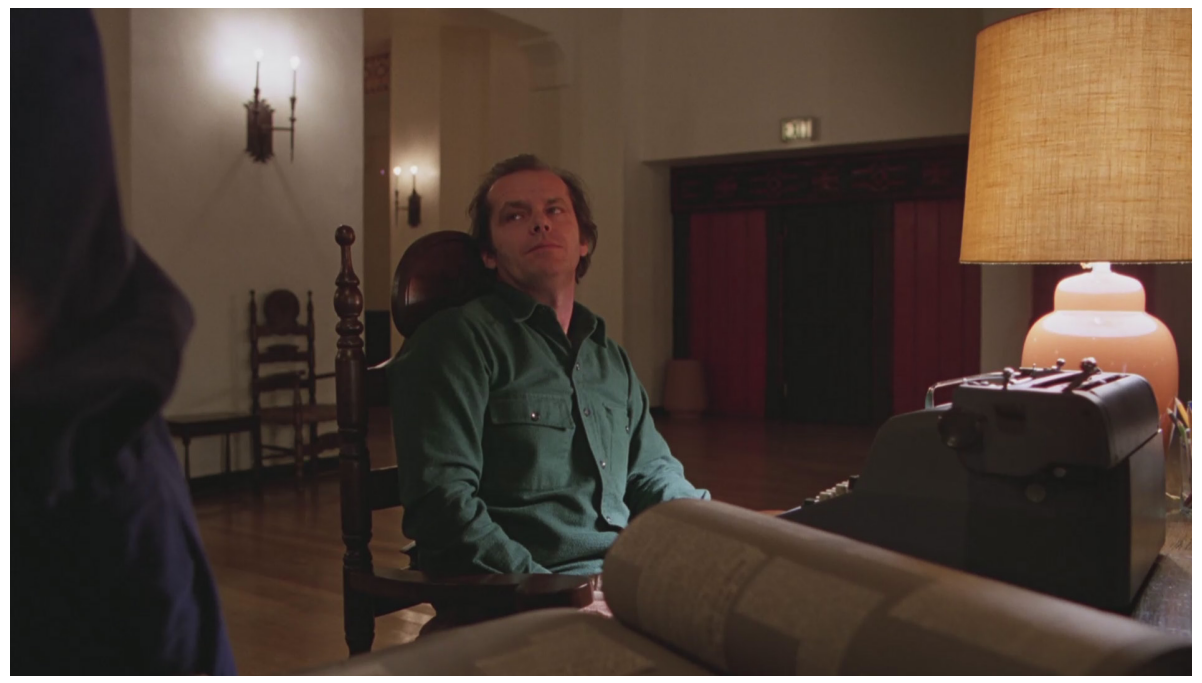

Ill.9 